\title{
Determinant Factors Affecting the Accounting Method Choices and Reported Profits of Big Industrial Companies in Indonesia
}

\author{
Susfa Yetti \\ Lecturer of Faculty of Economics and Business of Jambi University \\ Afrizal \\ Associate Professor of Faculty Economics and Business of Jambi University
}

\begin{abstract}
This study aims to find out the determinant factors affecting the choice of accounting methods and the reported profit of big industrial companies in Indonesia. The results showed: (1) Total assets of big industrial companies, DER and bonus managers simultaneously had a significant influence on the choice of Accounting Methods which increase profit of the companies. This was supported by Nagel R Square of 0.558 or it could be interpreted that the model could give an effect to change variations of the choice of accounting methods by $58.80 \%$. (2) The debt of big industrial companies which is represented by debt to equity ratio has a significant effect on the choice of Accounting Methods. It means that the greater the company's debt, the greater the tendency of the company to select the accounting methods that increase reporting of company's profit. (3) Big industrial companies that have a bonus managers have significant effect on the choice of the Accounting Method because the Wald test value is $59,356>2$ or $p$-value $0,00<$ alpha 0,05 . This means that the greater the bonus manager of the company, the greater the tendency of the company to select accounting methods that increase reported profit. (4) Sales volume, Debt to Equity Ratio, and Bonus managers simultaneously have significant effect on the reporting of company's profit of big industrial companies in Indonesia. This was stated by $F_{a}$ which was greater than $F_{\text {table }}$ or $377.82>1.96$ at $(\alpha=$ 0.05 ; k-1; Nk) or P value $0,000<0.05$ and supported by Adjusted R Square of 0.641 or $64.10 \%$ or it can be interpreted that this model can influence the change variations of reported profit of companies $64.10 \%$. (5) Companies with a greater sales volume have a significant effect on reporting of company's profit. This was indicated by $\mathrm{t}_{\mathrm{a}}>\mathrm{t}_{\text {-table }}$ at $(\alpha=0.05 ; \mathrm{N}-\mathrm{k})$ or $33,642>1.96(\alpha=0.05 ; \mathrm{N}-\mathrm{k})$ or with a significance level of $\mathrm{P}$ value $0,000<0.05$. This means that the greater the company's sales volume, the greater the company's profit will be.
\end{abstract}

Key words: Asset, Debt to equity ratio, Accounting methods, and Profit

DOI: $10.7176 /$ RJFA/10-20-09

Publication date:October $31^{\text {st }} 2019$

\section{INTRODUCTION}

\subsection{Research Background}

Research on Accounting tends to relate to how to report business activities. Tendency of such research is because that accounting provides many advantages or practical benefits that can help owners and creditors to understand the company's condition. Actually, the practical benefits of accounting had already existed before accounting researchers began to do their researches

The academic accounting community influences the development of accounting through research.

Management as the one who carries out decision making in the company and as the person responsible for preparing financial data, and it certainly influences how accounting practices are implemented. Decision makers are usually in choosing certain alternative actions based on their want and preferences. According to the theory there are several accounting methods that can increase corporate reported earnings, and some of those are not. Thus, companies have different motives in selecting the accounting method they do.

Bonus is one of the factors that can influence managers in determining the choice of the use of an accounting method. Big companies also have a tendency to select accounting methods according to what their needs and so to Companies with big of debts.

From the explanation above, it can be seen that the complexity of selecting an accounting method depends very much on the motivation and needs of the companies.

If it is associated to the object of the company for research, it would be more interesting to examine the company which is matching to the type of business, and also, for the case in Indonesia, it would be even more interesting if what are being studied are companies that have gone public. It is because companies that have gone public are mostly the best big companies in Indonesia. In addition, the company's financial statements that have gone public will be read and used by most interested parties.

Generally accepted accounting principles or Indonesian SAK provide alternatives of accounting methods that can be selected by companies to use in their financial reporting or reported earnings.. For industrial companies, 
there are several accounting methods offered, including; inventory method consisting of 3 alternative choices of accounting method, depreciation method consisting of 8 choices of accounting method, and capitalization method consisting of 3 alternative choices of accounting method.

Indonesia Stock Exchange (IDX) has grown rapidly in the past ten years, as seen from the number of companies that go public, or companies listed on the IDX to sell their shares. In 1987, it was only 24 listed companies sold their shares, and by the end of 2018 , the company that had registered was 633 companies and parts of them are industrial companies.

From the above research background, it appears that the principal study in this research is financial accounting using an approach of positive accounting research in which it is also based on the agency theory.

\subsection{Research Problems}

Based on the above research background, the research problem can be formulated as follows:

1) What is the effect of the company's total assets, company's sales volume, the company's capital structure, and the manager's bonus (simultaneously) on the choice of the company's accounting methods?

2) What is the effect of th company's total assets, company's sales volume, company's capital structure, and the manager's bonus (partially) on the choice of the company's accounting methods?

3) What is the effect of the company's total assets, company's sales volume, the company's capital structure, and the manager's bonus (simultaneously) on reported earning (profit) of the companies ?

4) What is the effect of the company's total assets, company's sales volume, the company's capital structure, and the manager's bonus (partially) on reported earning (profit) of the companies?

\subsection{Research Objectives}

The purpose of this study is to obtain empirical evidence and to find clarity on the factors influencing companies in selecting accounting methods. The purposes of this study in more detail are to:

1) To analyze the effect of the company's total assets, company's sales volume, the company's capital structure, and the manager's bonus (simultaneously) on the choice of the company's accounting methods.

2) To analyze the effect of th company's total assets, company's sales volume, company's capital structure, and the manager's bonus (partially) on the choice of the company's accounting methods?

3) To analyze the effect of the company's total assets, company's sales volume, the company's capital structure, and the manager's bonus (simultaneously) on reported earning (profit) of the companies?

4) To analyze the effect of the company's total assets, company's sales volume, the company's capital structure, and the manager's bonus (partially) on reported earning (profit) of the companies?

\subsection{Research Contribution}

The results of this study are expected to provide 2 main contributions, namely:

1) Operational. It is expected that the information can be useful for the users of companies financial statements, especially owners of the company and practitioners outside the company in interpreting and understanding the information of the reporting of company's earnings so as to assess the company's performance correctly and objectively.

2) Science Development. It is expected to be able to contribute in the development of accounting science in Indonesia, specifically, how the process of thinking to conduct research related to "Positive Accounting Research" and the existence of new discoveries of variables that have not previously been investigated by other parties, as well as a reconciliation of factors can influence the company in selecting the company's accounting methods. It is also expected to be used as a reference material for similar research and further research.

\section{LITERATURE REVIEW}

\subsection{Agency Theory}

Schroeder, Clark, and McCullers (1991) define agency as a relationship through agreement between two parties, on the one hand, a manager acts as an agent, and on the other hand, the owner acts as the principal, for example, the relationship between shareholders and the managers of their company which is an agency relationship, the relationship between managers and auditors, and furthermore the relationship between auditors and shareholders.

In agency theory, agent and principal are assumed to be rational people want to maximize their own utilities. The owners wish a big investment return, meanwhile the managers have the desire to increase their own wealth.

\subsection{Accounting Method}

The accounting methods that are generally used by companies which are on an accounting basis including to industrial companies are inventory accounting methods, depreciation accounting methods, and capitalization 
accounting methods. Other accounting methods are not mentioned above are classified as specific accounting methods according to the business type.

In line with the understanding of the accounting method, it is the procedures for carrying out accounting principles. Choices of using accounting methods are common things to be done, it is meaning that these actions are common as long as the choices are made in accordance with applicable financial accounting standards (SAK).

The numbers in a company's financial statements can be influenced by: economic factors, spending decisions, industry factors, and decision making on the choice of accounting methods used. That Foster's opinion showed that the use of accounting methods is one factor that also determines the numbers in the company's financial statements.

\subsubsection{Inventory Accounting Method}

The term of Inventory is goods held for sale in the normal condition of a company. In the case of industrial companies, the inventory also includes goods that are in the process of production or that will be included in the production process.

From the definition of inventory above, it can be concluded that inventory is goods intended for sale in the normal condition of a company operation, and what is also included in inventory are raw materials that will be used for production, raw materials that are in the process of production, and raw materials that have been finished being produced which is ready for sale.

\subsubsection{Capitalization Accounting Method}

The decision whether an expenditure is to be capitalized or to become expensed requires considerations. If an expenditure will provide benefits for the coming period then the expenditure is must be capitalized or used as an asset. If an expenditure only provides benefits in the current period, then the expenditure will be an expense in that period.

\subsection{Decision Making}

Making a choice between two or more alternatives is a decision. before a decision is taken by an individual or by a manager in the company, of course, there is a process, and the process is a decision-making process.

\subsection{Company's Total Asset and Sale Volume}

Total assets, is the total assets owned by the company at a certain time. Sales volume, is the volume of sales of a company in a certain period, for example. The fact that the big companies prefer to select alternative accounting methods that can minimize their profit. Conversely, small companies are often interested in selecting accounting methods that provide greater or higher their profit.

\subsection{Capital Structure}

The capital structure used in this study is Debt to Equity Ratio (DER) which is the relationship between long-term debt and it owner's capital, like this formula:

DER $=$ ratio of Long-term Debt to Owner's Capital

The behaviour of the company's management relating to the choice of accounting methods is also influenced by the company's capital structure, this is due to the limitations in the credit agreement between the companies and its bankers or creditors.

\subsection{Bonus}

Bonus are an important mechanism for encouraging and motivating managers to achieve organizational goals. In order for managers to act in the best interests of the company, the owner proposes a bonus plan allowing top manager to take part in increasing the company's wealth. This bonus plan can be in the form of giving stock options or bonuses based on company performance reports. The existence of a manager's bonus plan is very important in order to encourage managers to act in the best interests of the company.

\subsection{Choice of Accounting Methods}

The choice of accounting methods to be used by the company is one of the tasks which is the responsibility of the company's management.

Theoretically reviewed, the choice of accounting methods that are considered good is which method is the most able to bring together income and expenses (matching cost and revenue). In practice, the choice of accounting methods tends not to be based on the concept of matching costs and revenue but is driven more by the motives of different managers. Different managers' motives in selecting alternative accounting methods will cause 
the selected accounting methods to be different, for example: there are managers who have the desire to increase earnings and in certain conditions there are managers who wish to reduce earnings.

\subsection{Profit and Reported Earnings (Profit).}

Earning is one of the important numbers in the company's financial statements. Earning is always a special concern for other users of financial statements. For the management of earnings can be used as a measure of performance in running the company for a certain period. For creditors and profit investors is one measure of company performance in a certain period

The intended earning can be in the form of profit before taxes/earnings before taxes and profit after taxes/earnings after taxes originating from financial statements (audited) that are officially published on the Indonesia. In this research the earning we used is the earning after taxes (EAT) or Profit after taxes.

\subsection{Research Framework and Hypothesis}

Starting from the determinat facors, a flow paradigm is prepared such as Figure 02 below:

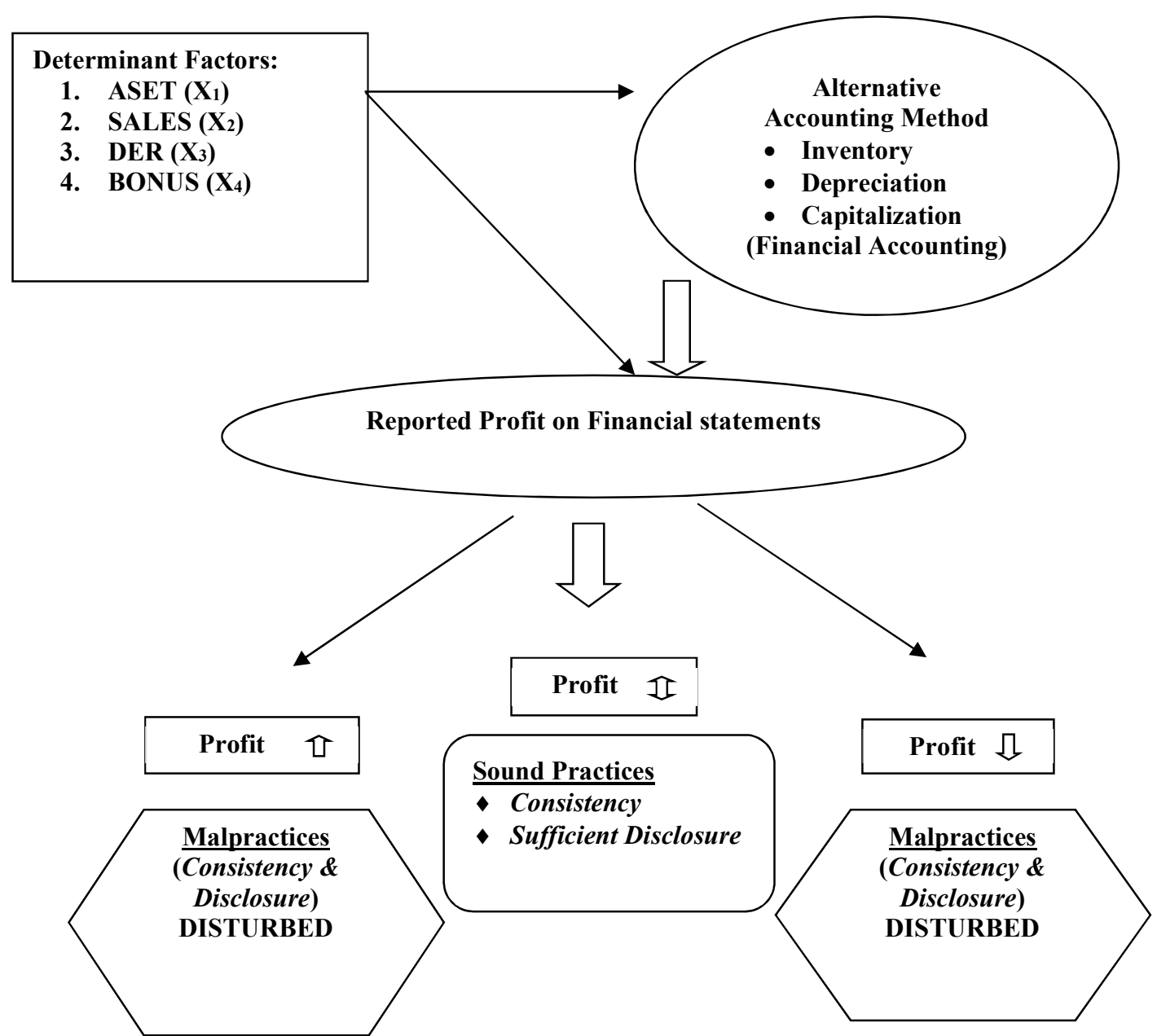

Figure.02. Paradigm of Research Framework

From the research paradigm above, the mathematical equation model can be formulated as follows:

$$
\mathrm{Y}_{\mathrm{i}}=f\left(\mathrm{X}_{1}, \mathrm{X}_{2}, \mathrm{X}_{3}, \mathrm{X}_{4}, \varepsilon\right)
$$

\subsection{Hypothesis}

Starting from the problems and the research framework can be deduced hypothesis as follows:

1) The company's total assets, company's sales volume, the company's capital structure, and the manager's bonus (simultaneously) influence significantly on the choice of the company's accounting methods. 
2) The company's total assets, company's sales volume, company's capital structure, and the manager's bonus (partially) influence significantly on the choice of the company's accounting methods.

3) To analyze the effect of the company's total assets, company's sales volume, the company's capital structure, and the manager's bonus (simultaneously) influence significantly on reported earning (profit) of the companies.

4) To analyze the effect of the company's total assets, company's sales volume, the company's capital structure, and the manager's bonus (partially) influence significantly on reported earning (profit) of the companies.

\section{RESEARCH METHOD}

3.1. Research Object

The object of this research is industrial companies listed on the Indonesia Stock Exchange (IDX) for the 2014 to 2018 period. The number of industrial companies registered or that have gone public on the IDX is 127 industrial companies or with pooling 5 years periode of the research there will be 635 companies.

\subsection{Research Method}

In this study, the research method used is the survey method, which is collecting data (information) from several companies included in the research object. Data collection is carried out using Questionnaire (see Appendix-2). While, the data used are primary and secondary data, that is, both directly taken from company as the object of research and data from other relevant institutions.

\subsection{Population and Sample}

The population of this study is industry companies listed on the Public List of the Indonesia Stock Exchange (IDX) until the end of 2018 in which there are 164 industrial companies. The population of this study took company data 5 years in a row which id from 2014 - 2018. While the sample of this study used a purposive sampling method (meaning; the samples selected according to criteria established and needed for the purpose of this study). From the 164 industrial companies, it was selected to be samples 127 industrial companies or with pooling 5 years periode of the research there will be 635 companies.

\subsection{Operationalization of Variables}

The independent variables discussed in the study are limited to four main variables: total asset variable $\left(\mathrm{X}_{1}\right)$, sales volume variable $\left(\mathrm{X}_{2}\right)$, Debt to Equity ratio or DER variable $\left(\mathrm{X}_{3}\right)$, and bonus variable $\left(\mathrm{X}_{4}\right)$.

The dependent variable of this study consists of two main variables, namely the accounting method variable $\left(\mathrm{Y}_{1}\right)$, and the other dependent variable is corporate earnings reporting $\left(\mathrm{Y}_{2}\right)$ in which it is earnings reporting after tax (EAT). Further explanation regarding each variable is as follows:

\section{(1) Company Total Asset $\left(\mathbf{X}_{1}\right)$ and Sales Volume $\left(\mathbf{X}_{2}\right)$}

The scale of the company is measured by measuring tools as follows:

- Total assets (in rupiah) as of December 31, 2014 to December 31, 2018. Symbolized with $X_{1}$

- Sales volume (in rupiah) from 2014 to 2018. Symbolized with $\mathrm{X}_{2}$

(2) Capital Structure Variable or Leverage. $\left(\mathbf{X}_{3}\right)$

The capital structure variable in this study is the ratio of long-term debt to equity or the ratio of long-term debt to equity.it is also known as Debt to Equity Ratio (DER).

\section{(3) Manager Bonus Variable $\left(\mathbf{X}_{4}\right)$}

The manager bonus is determined through a contract between the owner and managers and calculated based on earnings (profits) obtained by the company.

In this study, the intended bonus is an agreement to get a bonus at the end of the year to Top Manager/President Director/Principal Director which is a reward for his success in achieving certain targets..

\section{(4) Accounting Methods Variable ( $\left.\mathbf{Y}_{1}\right)$}

Accounting methods are procedures is used for implementing accounting principles to prepare financial statement. The writer realizes that the current accounting methods in Indonesia are numerous. There are accounting methods that can be generally applied to all companies, and there are also accounting methods that can only be applied to certain types of companies.

(6) Company's Earning Reporting Variable $\left(\mathbf{Y}_{2}\right)$.

The intended profit reporting is a substitute term for the Profit that has been reported in the Company's Financial 
Statements. Corporate earnings reporting variable $\left(\mathrm{Y}_{2}\right)$, which is the reporting of earnings after tax or Earning After Taxes (EAT) or Profit after Taxes.

\subsection{Data Analysis Method}

In this study, quantitative analysis methods are used. Both descriptively and inferentially. Descriptive analysis is done by making a direct tabulation of the data of the variables to be analyzed, then comparing the percentage values and the average. Furthermore, inferential analysis to see the effect of independent variables on the accounting method used Multiple Logistic Regression Analysis because of its conformity with the measurement scale of the independent variables and the measurement scale of the accounting method. The choice of multiple logistic regression or logit model is considered suitable because the dependent variable of this study is nominal or dichotomic. In addition, multiple logistic regression is quite widely used by researchers in the choice of previous accounting methods.

Specifically, to see the effect of independent variables on company earnings reporting, multiple regression analysis is used because the scale of measurement of independent variables and the dependent variable (earnings reporting) is ratio. Thus, for this study, the regression model can be formulated as follows:

1. To determine the effect of the manager's bonus $\left(\mathrm{X}_{4}\right)$, total assets $\left(\mathrm{X}_{2}\right)$, scale - sales volume $\left(\mathrm{X}_{3}\right)$, capital structure of the company $\left(\mathrm{X}_{3}\right)$ to The accounting method $\left(\mathrm{Y}_{1}\right)$ and to reported profit $\left(\mathrm{Y}_{2}\right)$, the model is as follows:

a. Logistics transformation:

$\left.\operatorname{Logit} P\left(Y_{1 i}\right)\right)=\beta_{0}+\beta_{1} X_{1}+\beta_{2} X_{2}+\beta_{3} X_{3}+\beta_{4} X_{4}+\varepsilon_{i}$

b. The logistic regression model:

$\mathrm{P}\left(\mathrm{Y}_{1 \mathrm{i}}\right)=1 /\left\{1+\exp \left[-\left(\beta_{\mathrm{o}}+\beta_{1} \mathrm{X}_{1}+\beta_{2} \mathrm{X}_{2}+\beta_{3} \mathrm{X}_{3}+\beta_{4} \mathrm{X}_{4}\right)\right]\right\}$

c. The linear regression model:

$Y_{2 i}=\beta_{o}+\beta_{1} X_{1}+\beta_{2} X_{2}+\beta_{3} X_{3}+\beta_{4} X_{4}+\varepsilon_{i}$

2. To find out the influence of manager bonus plan variables, company scale, and company capital structure (individually) on the accounting method, the model is as follows:

$\mathrm{P}\left(\mathrm{Y}_{1}\right)=1 /\left\{1+\exp \left[-\left(\beta_{\mathrm{o}}+\beta_{1} \mathrm{X}_{1}+\varepsilon_{\mathrm{i}}\right)\right]\right\}$
$\mathrm{P}\left(\mathrm{Y}_{1}\right)=1 /\left\{1+\exp \left[-\left(\beta_{\mathrm{o}}+\beta_{2} \mathrm{X}_{2}+\varepsilon_{\mathrm{i}}\right)\right]\right\}$
$\mathrm{P}\left(\mathrm{Y}_{1}\right)=1 /\left\{1+\exp \left[-\left(\beta_{\mathrm{o}}+\beta_{3} \mathrm{X}_{3}+\varepsilon_{\mathrm{i}}\right)\right]\right\}$
$\mathrm{P}\left(\mathrm{Y}_{\mathrm{i}}\right)=1 /\left\{1+\exp \left[-\left(\beta_{\mathrm{o}}+\beta_{4} \mathrm{X}_{4}+\varepsilon_{\mathrm{i}}\right)\right]\right\}$
and
$\mathrm{P}\left(\mathrm{Y}_{2 \mathrm{i}}\right)=1 /\left\{1+\exp \left[-\left(\beta_{\mathrm{o}}+\beta_{1} \mathrm{X}_{1}+\varepsilon_{\mathrm{i}}\right)\right]\right\}$
$\mathrm{P}\left(\mathrm{Y}_{2 \mathrm{i}}\right)=1 /\left\{1+\exp \left[-\left(\beta_{\mathrm{o}}+\beta_{2} \mathrm{X}_{2}+\varepsilon_{\mathrm{i}}\right)\right]\right\}$
$\mathrm{P}\left(\mathrm{Y}_{2 \mathrm{i}}\right)=1 /\left\{1+\exp \left[-\left(\beta_{\mathrm{o}}+\beta_{3} \mathrm{X}_{3}+\varepsilon_{\mathrm{i}}\right)\right]\right\}$
$\mathrm{P}\left(\mathrm{Y}_{2 \mathrm{i}}\right)=1 /\left\{1+\exp \left[-\left(\beta_{\mathrm{o}}+\beta_{4} \mathrm{X}_{4}+\varepsilon_{\mathrm{i}}\right)\right]\right\}$

Description:

$\beta_{\mathrm{o}}=$ intercept

$\beta_{\mathrm{I}}=$ slope coefficient

$\mathrm{X} 1=$ total assets

$\mathrm{X}_{2}=$ sales volume

$\mathrm{X}_{3}=$ capital structure of the company

$\mathrm{X}_{4}=$ manager's bonus

$\mathrm{Y}_{1}=$ accounting method

$\mathrm{Y}_{2}=$ corporate reported profit

$\varepsilon_{\mathrm{I}}=$ disturbance or error term of population

\section{RESULT AND DISCUSSION}

\subsection{Overview of Research Objects}

In 1987, the Jakarta Stock Exchange (now the Indonesia Stock Exchange) was established. In 1987, there were only 24 listed companies selling their shares on the Jakarta Stock Exchange. In the last 30 years, the Indonesian Stock Exchange has developed quite rapidly, this can be seen from the number of companies that went public or listed on the IDX to sell their shares and by the end of 2018 the listed companies had sold 633 companies.

From the 633 companies listed on the IDX, there are 164 companies that are classified as industrial companies.

\subsection{Analysis on the Effect of Assets, DER and Bonus of Manager toward Accounting Methods}

Testing the influence of independent variables on the accounting method for 5 years data from 2014 to 2018 used 
Multiple Logistic Regression Analysis.

In initial step, the autocorrelation test will be performed using the Durbin Watson-test, collinearity testing using the coefficient of determination $\mathrm{R} 2$, and heteroscedasticity testing using the co-variance matrix.

Based on the test results of the 2014 to 2018 period data, it can be stated that there is no significant autocorrelation, because the Durbin Watson test value is close to 2 (see Appendix-20) namely; D-W $=2,112$. It is also known that there is no collinearity of the relationship between the independent variable and the dependent variable, because the adjusted R2 value is 0.641 which means that it is quite high and which shows that many independent variables individually have an influence on the dependent variable. Noting the results of the tests above, the data analysis can be continued.

a) The first hypothesis testing is to determine the effect of independent variables on the accounting method ( $\left.Y_{1}\right)$. From the calculation results, the estimation of the Multiple Logistic Regression equation is obtained (see Appendix-4) as follows:

Accounting Method $\left(\mathrm{Y}_{1}\right)=0.670+0.000 \mathrm{X} 1+0.715 \mathrm{X}_{2}+3.967 \mathrm{X}_{4}$

The results of calculating of the logistical effects of the independent variables individually on the choice of the Accounting Method $\mathrm{P}\left(\mathrm{Y}_{1}\right)$ can be seen in the following 5-1:

Table.4-1. Magnitude of the Effect of Logistics Independent variables on the Choice of Accounting Methods ( $\left.\mathrm{Y}_{1}\right)$ from 2014 to 2018 in the Summary Model.

Model Summary

\begin{tabular}{|l|r|r|r|}
\hline Step & -2 Log likelihood & Cox \& Snell R Square & \multicolumn{2}{|c|}{ Nagel kerke R Square } \\
\hline 1 & $623,163^{\mathrm{a}}$ &, 453 &, 558 \\
\hline
\end{tabular}

a. Constant is included in the model.

b. The cut value is ,500

Table.4-2. The Significance of Logistic Effects of Independent Variables on the Choice of Accounting Methods ( $\left.\mathrm{Y}_{1}\right)$ from 2014 to 2018 in Variables in The Equation.

Variables in the Equation

\begin{tabular}{|c|c|c|c|c|c|c|}
\hline & B & S.E. & Wald & $\mathrm{df}$ & Sig. & $\operatorname{Exp}(B)$ \\
\hline $\mathrm{X}_{1}$ &, 000 &, 000 & ,759 & 1 & ,384 & 1,000 \\
\hline $\mathrm{X}_{3}$ &, 715 & 029 & 3,645 & 1 &, 022 & ,516 \\
\hline $\mathrm{X}_{4}(1)$ & 3,967 &, 515 & 59,356 & 1 &, 000 &, 019 \\
\hline Constant & 3,990 & ,509 & 61,466 & 1 &, 000 & 54,059 \\
\hline
\end{tabular}

Based on table 5-1 above, it can be concluded that the effect of the independent variables simultaneously on the choice of accounting methods $\left(\mathrm{Y}_{1}\right)$ is as follows:

Total Assets of big industrial companies $\left(\mathrm{X}_{1}\right)$, DER (Debt to Equity Ratio) $\left(\mathrm{X}_{3}\right)$, and Bonus Plans for their managers $\left(\mathrm{X}_{4}\right)$ have a significant effect on the choice of Accounting Methods $\left(\mathrm{Y}_{1}\right)$ which increases company earnings reporting. This is supported by Nagel R Square 0.558 or it can be interpreted that the model can influence the variation of changes in the choice of accounting methods by $58.80 \%$ and the remaining $41.20 \%$ variation in changes in the choice of accounting methods that have a tendency to increase profits determined by other variables not included in this model.

Based on table 5-2 above, it can be concluded that the effect of partially independent variables on the choice of accounting methods $\left(\mathrm{Y}_{1}\right)$ is as follows:

Total Assets of big industrial companies $\left(\mathrm{X}_{1}\right)$ do not have a significant influence on the choice of Accounting Methods $\left(\mathrm{Y}_{1}\right)$.

Debt of big industrial companies or represented by DER (Debt to Equity Ratio) $\left(\mathrm{X}_{3}\right)$ has a significant influence on the choice of Accounting Methods ( $\left.\mathrm{Y}_{1}\right)$. This is supported by a significance level of $0.022<0.05$ or strengthened by the Wald test value of 3,645>2. This means that the greater the company's debt the greater the tendency to select accounting methods that increase company earnings reporting.

Big industrial companies that have a bonus plan for their managers $\left(\mathrm{X}_{4}\right)$ have a significant influence on the choice of the Accounting Method ( $\left.\mathrm{Y}_{1}\right)$, because the Wald test value is 59,356>2 or P-value $0.00<$ alpha 0.05 . 
This means that the greater the bonus manager of the company will be more likely to select accounting methods that increase company earnings reporting.

\subsection{Analysis on the Effect of Sales, DER, and Bonus of Manager toward Company Earning}

Table 4-3. Magnitude of Effect of Independent Variables on Profit (Y2) Simultaneously in 2014-2018 in Summary Model.

Model Summary

\begin{tabular}{|l|r|r|r|r|}
\hline Model & \multicolumn{1}{|c|}{$\mathrm{R}$} & \multicolumn{1}{|c|}{ R Square } & Adjusted R Square & Std. Error of the Estimate \\
\hline 1 &, $801^{\mathrm{a}}$ &, 642 &, 641 & 155,591 \\
\hline
\end{tabular}

a. Predictors: (Constant), $\mathrm{X}_{4}, \mathrm{X}_{2}, \mathrm{X}_{3}$

Table.4-4. Significance of the Effect of Independent Variables on Profit (Y2) Simultaneously in 2014-2018 in ANOVA.

ANOVA $^{\mathrm{a}}$

\begin{tabular}{|ll|r|r|r|r|r|}
\hline Model & & Sum of Squares & \multicolumn{1}{|c|}{ df } & Mean Square & F & Sig. \\
\hline 1 & Regression & 274,000 & 3 & 960,000 & 377,815 &, $000^{\mathrm{b}}$ \\
& Residual & 152,000 & 631 & 240,000 & & \\
& Total & 426,000 & 634 & & & \\
\hline
\end{tabular}

a. Dependent Variable: $\mathrm{Y}_{2}$

b. Predictors: (Constant), $\mathrm{X}_{4}, \mathrm{X}_{2}, \mathrm{X}_{3}$

Table.4.5. Significance of the Effect of Independent Variables on Profit (Y2) Partially from 2014-2018

\section{Coefficients}

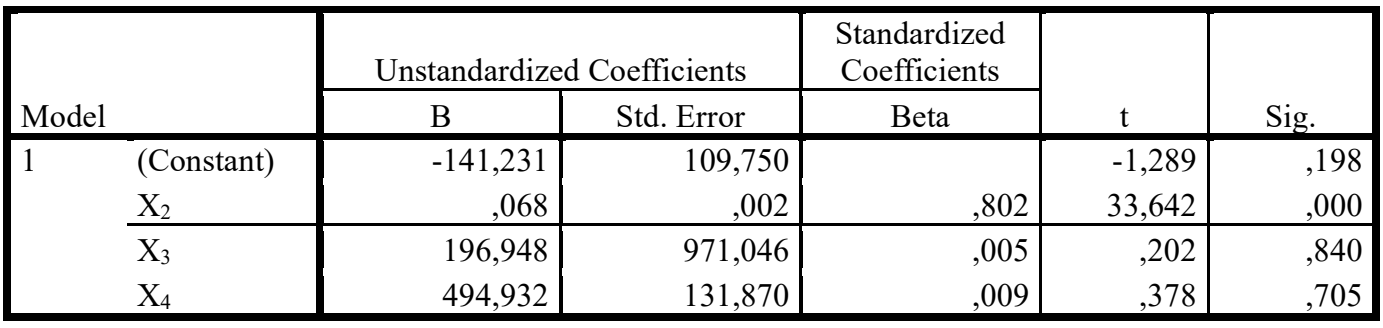

The second test: to analyze the effect of independent variables on reporting earnings $\left(\mathrm{Y}_{2}\right)$ or earnings after tax (EAT) used Multiple Regression Analysis with OLS Method. From the calculation results, we estimate the Multiple Linear Regression equation (see Appendix-3) as follows:

EARNINGS $\left(\mathrm{Y}_{2}\right)=-141,231+0,068$ Sales $\left(\mathrm{X}_{2}\right)+196,948$ DER $\left(\mathrm{X}_{3}\right)+494,932$ Bonus $\left(\mathrm{X}_{4}\right)$

Based on the regression equation above, it can be concluded that the effect of the independent variables simultaneously on reporting of earning after tax (EAT) is as follows:

Sales volume or $\left(\mathrm{X}_{1}\right)$, DER (Debt to Equity Ratio) or $\left(\mathrm{X}_{3}\right)$, and Bonus Plans for managers $\left(\mathrm{X}_{4}\right)$ simultaneously have a significant effect on the earnings reporting of big industrial companies in Indonesia, this is stated by $\mathrm{F}$ arithmetic greater than $\mathrm{F}$ arithmetic $>\mathrm{F}$ Table or $377.82>1.96$ at $(\alpha=0.05 ; \mathrm{k}-1 ; \mathrm{Nk})$ or $\mathrm{P}$ value $0,000<0.05$ and supported by Adjusted R Square 0.641 or $64,10 \%$, or it can be interpreted that this model can influence the variation in earnings reporting changes by $64.10 \%$ and the remaining $35.90 \%$ variation in changes in earnings reporting is determined by other variables not included in this model.

$\square \quad$ Companies with a greater sales volume have a significant effect on corporate earnings reporting (Profit). This is indicated by $t_{\text {count }}>t_{\text {table }}$ at $(\alpha=0.05 ; \mathrm{N}-\mathrm{k})$ or 33,642>1.96 $(\alpha=0.05 ; \mathrm{N}-\mathrm{k})$ or with a significance level of $\mathrm{P}$ value $0,000<0.05$. This means that the greater the company's sales volume will cause the company's earnings to increase as well. The results of the above studies are consistent and in accordance with the size hypothesis (Watts and Zimmerman: 1986), with the results of research Cahan (1988), Trombley (1989), and Pourjalali (1992).Contrary to the results of research by Bathke, Lorek, and Willinger (1989), and Ali and Kumar (1994).,

Companies with greater debt or corporate DER do not have an influence on company earnings reporting. Companies with more manager bonus plans do not have a significant effect on the earnings reporting of big industrial companies listed on the Indonesia Stock Exchange.

V. CONCLUSION AND SUGGESTION 


\subsection{Conclusion}

(1) Total Assets of big industrial companies , Debt to Equity Ratio, and Bonus managers simultaneously have a significant effect on the choice of Accounting Methods which increases company earnings reporting. This is supported by Nagel R Square 0.558 , or it can be interpreted that the model can influence the variation of changes in the choice of accounting methods by $58.80 \%$, and the remaining of $41.20 \%$ variation in changes in the choice of accounting methods that have a tendency to increase profits determined by other variables not included in this model.

(2) Total Assets of big industrial companies do not have a significant influence on the choice of Accounting Methods.

(3) Debt of big industrial companies or represented by Debt to Equity Ratio has a significant influence on the choice of Accounting Methods. This is supported by the significance level of $0.02<0.05$ or strengthened by the Wald test value of $3,645>2$. This means that the greater the company's debt, the greater the tendency to select accounting methods that increase corporate earnings reporting.

(4) Big industrial companies that have a bonus plan for their managers have a significant influence on the choice of the Accounting Method, because the Wald test value is $59.356>2$ or p-value $0.00<$ alpha 0.05 . This means that the greater the bonus manager of the company, the greater the tendency to select accounting methods that increase company earnings reporting.

(5) Sales volume or Debt to Equity Ratio or , and Bonus managers (X4) simultaneously have a significant effect on the earnings reporting of big industrial companies in Indonesia, this is stated by $\mathrm{F}$ arithmetic greater than F Table or $377.82>1.96$ at $(\alpha=0.05 ; \mathrm{k}-1$; Nk) or P value $0,000<0.05$ and supported by Adjusted R Square 0.641 or $64.10 \%$, or it can be interpreted that this model can influence the variation in earnings reporting changes of $64.10 \%$ and the remaining $35.90 \%$ variation in changes in earnings reporting is determined by other variables not included in this model.

(6) Companies with a greater sales volume have a significant influence on corporate earnings reporting (Profit). This is indicated by $\mathrm{t}_{\mathrm{a}}>\mathrm{t}_{\text {table }}$ at $(\alpha=0.05 ; \mathrm{N}-\mathrm{k})$ or $33,642>1.96(\alpha=0.05 ; \mathrm{N}-\mathrm{k})$ or with a significance level of $\mathrm{P}$ value $0,000<0.05$. This means that the greater the company's sales volume will cause the company's profits to increase as well.

(7) Debt to Equity Ratio does not have a significant effect on earnings or corporate earnings reporting.

(8) Big industrial companies that have a bonus plan for their managers do not have a significant effect on earnings or company earnings reporting.

\subsection{Suggestion}

(1) Factors that influence the choice of the accounting method are sales volume, total debt, and manager's bonus. Its meant that; part of hypothesis of Watt and Zimmerman is still valid untill today.

(2) Understanding the factors influencing the choice of accounting methods is carried out by having to pay attention to whether there is a change (up or down) in the value or unit of measure of the variable and pay attention to the causal relationship, namely whether a positive or negative relationship to the choice of accounting methods which raises company earning reporting.

\section{REFERENCES}

Afrizal (2018)., Accounting Theory”,, Salim Media Indonesia Publisher. Jambi. $1^{\text {st }}$ Edition. pp. 2-3.

Amah Kalu Ogbonnaya Amauwa Basil (2019).,"Effect of Financial Reporting Quality on Financial Performance”., RJFA, Vol.10.No.11.

Ayitenew Temesgen and Lakech Estifanos (2018) "Determinants of Internal Audit Effectiveness: Evidence from Gurage Zone"., Research Journal of Finance and Accounting.

Ashar, Kalpesh (2019)., "Financial Accounting: Essentials You Always Wanted to Know”., Vibrant Publisher. $4^{\text {th }}$ Edition". pp. 7

Blokdyk, Gerardus (2019)., Hedge Accounting A Complete Guide”. Emereo Pty.Ltd. Publisher International Edition. pp. 21

Gleim, Irvin M (2019)., "Financial Accounting and Reporting”., CPA Review. Paperback. With Connect..pp. IAI (2018)., "Standar Akuntansi Keuangan". Edisi Ikatan Akuntan Indonesia, 2018.pp. 8-9

Joyce, William B (2018). "Managerial Compensation and the Provision for Loan Losses (Agency Theory)". Dissertation.

Mohammad Dabaghie (2019)., "The Impact of Accounting Disclosure Levels on Improving theMental Image of Pharmaceutical Companies in Jordan"., RJFA, Vol.10.No.8.

Nur eny Lolo and Muh. Rum (2019).,'Environmental Green Accounting and Auditing Practice".'RJFA, Vol.10.No.08.,2019.

OECD (2018)., National Accounts of OECD Countries, Financial Account”.. OECD Publisher.pp.2.

Smith, Jay M. and K. Fred Skousen (2018)., "Intermediate Accounting"., $14^{\text {th }}$ Edition, Cincinnati; College 
Division. South-Western Publishing Co.

Walther, Larry M (2019)., "Managerial Accounting”, Amazon Publisher, $17^{\text {th }}$ International Edition.

Wild John J (2018)., "Managerial Accounting"., Paperback. With Connect 2018. $6^{\text {th }}$ Edition.

Urip, Sri (2018).," CSR Strategies, Corporate Social Responsibility: For a Competitive Edge in Emerging Markets"., A John Wiley \& Sons (Asia), Ltd, Publication. Singapore.

Visser, Matten, Pohl, and Tolhurst (2018).," The A to Z Corporate Social Responsibility"., A John Wiley \& Sons, Ltd, Publication. Revised Edition.

Weygandt, Kimmel, and Kieso (2018)., "Financial Accounting”., John Wiley \& Sons, Ltd, Publication. IFRS Edition.

Whittingtin and Bain (2018)., "Financial Accounting and Reporting"., Wiley CPA Aexel Exam Review.

Temesgen A Birhan (2018) "Determinants of turnover Tax Collection Effectivnes: The Case of West Gojiam"., Research Journal of Finance and Accounting.

William Smart Inyang, John Ogenyi Oboh, and Rex Tobechukwu Nwabuikem (2019).,'Ethical Thoughts in Accounting And Their Effects On Accounting Practice". RJFA, Vol.10.No.06.

Author: Afrizal (D’04-D'08--CH '15--'19). Dean of Economics Faculty of Jambi University (2004-2008), Dean of Economics Faculty of Jambi University (2008-2012), Chairman of Indonesia Accountants Institute for Jambi Province (2015-2019). Birth: 27 July 1959 Bukittinggi, Indonesia. Education: Bachelor in Accounting at Andalas University, Padang, Indonesia. Master in Accounting 1996 at Padjadjaran University, Bandung, Indonesia. Doctor in Accounting 1999 at Padjadjaran University, Bandung, Indonesia. 